\title{
Evaluation of Visible Implant Elastomer for Marking Juvenile Red Drum
}

\author{
Amanda M. Bushon, Gregory W. Stunz,* and Megan M. Reese \\ Department of Life Sciences, Texas A\&M University-Corpus Christi, \\ 6300 Ocean Drive, Corpus Christi, Texas 78412-5869, USA
}

\begin{abstract}
Visible implant elastomer (VIE) was evaluated for marking juvenile red drum Sciaenops ocellatus in experimental studies. We tested VIE on hatchery-reared red drum (standard length, 29.6-38.7 mm; SE, 0.23) in a laboratory study to examine mortality, tag retention, and growth effects associated with the marking method. We examined two tagging locations and two control treatments in anesthetized and unanesthetized fish. Red drum were tagged below and parallel to the dorsal fin and above and parallel to the anal fin. Five fish were anesthetized, marked, and stocked into replicated tanks and held for $14 \mathrm{~d}$. Tag retention was $100 \%$, and overall mortality was $10 \%$. The mortality of fish tagged below the dorsal fin was $0 \%$, whereas that of fish tagged above the anal fin was $40 \%$ (SE, 30.5). No significant difference in growth rates was observed between the marked and unmarked treatment groups. A field study was performed with wild and hatchery-reared red drum marked with VIE and released at three replicate sites in sea grass beds. The recapture rate was $1.3 \%$, and marked fish were collected at 1 and $3 \mathrm{~d}$ postrelease at distances of $15-45$ and $200 \mathrm{~m}$ from the release point. The results suggest that VIE marking of red drum has little effect on mortality and growth when fish are tagged dorsally and that VIE is a viable tool for short-term experiments requiring identification of small, juvenile red drum.
\end{abstract}

Marking and tagging are effective tools used by fisheries biologists to gain information about the life history and migration patterns of fishes; however, there are few techniques for marking small or juvenile fish whose total length (TL) is less than $50 \mathrm{~mm}$. Such techniques have included fin clipping (Haines and Modde 1996), cold branding (McFarlane et al. 1990), use of subcutaneous wire microtags (Bumguardner 1990, Malone et al. 1999), spray paint marking (Szedlmayer and Howe 1995), otolith marking (Hendricks et al. 1994; Negus 1999; Jenkins et al. 2002), and identification by means of genetic markers (King et al. 1993). However, fin clips and cold branding can be hard to identify (Guy et al. 1996), and spray paint marking can have high mortality and low retention rates (Szedlmayer and Howe 1995). Many of the other

\footnotetext{
* Corresponding author: greg.stunz@tamucc.edu
}

Received June 2, 2006; accepted August 31, 2006 Published online April 5, 2007 techniques, such as wire microtagging, otolith marking, and use of genetic markers, require sacrificing the fish for identification and can be expensive.

Visible implant elastomer (VIE; Northwest Marine Technology, Inc.) is an inexpensive marking material that is relatively easy to apply and allows for visible identification. This two-part, silicone-based material is mixed before use and injected as a liquid beneath transparent or translucent tissue. The liquid cures into a pliable solid and is externally visible. The VIE marking technique is advantageous because the tag is pliable and only a small volume of the material is required to make a visible tag. Many studies have examined the use of VIE for marking fish larger than $50 \mathrm{~mm}$ (e.g., Bonneau et al. 1995; Morgan and Paveley 1996; Hale and Gray 1998; Close 2000; Catalano et al. 2001; Close and Jones 2002; Goldsmith et al. 2003; Fitzgerald et al. 2004; Olsen et al. 2004; Brennan et al. 2005). The few studies that have examined the use of VIE for marking fish smaller than $50 \mathrm{~mm}$ have shown that this is a viable approach with low mortality and high retention rates (Dewey and Zigler 1996; Haines and Modde 1996; Frederick 1997; Olsen and Vøllestad 2001). However, VIE marking has not been evaluated for the red drum Sciaenops ocellatus, an economically important fishery species. VIE marking may be a fast, efficient, and reliable means to effectively tag juvenile red drum. Assessment of a tagging technique for small (less than $50 \mathrm{~mm}$ ) individuals would greatly benefit future studies.

The red drum is an estuarine-dependent sciaenid found in the western Atlantic Ocean and throughout the Gulf of Mexico from Florida to Tuxpan, Mexico. It is considered to be the most important recreational sciaenid species and is one of the seven most soughtafter game fish in the Gulf of Mexico (Pattillo et al. 1997). Adults spawn near passes and tidal inlets from September through January (Holt et al. 1983; Rooker et al. 1998b). Tides carry their eggs and larvae into shallow estuaries, where they settle into their nursery habitat when their standard length (SL) is approximately 6-8 mm (Holt et al. 1983; Rooker et al. 1997, 1998a). However, more information is needed concerning their residence time and fine-scale movement patterns within the nursery habitat. 
Clearly, this information is vital to understanding the population dynamics of this important fishery species. It is also crucial, however, to understand the movement patterns of hatchery-reared red drum. Approximately 20-30 million hatchery-reared red drum fingerlings are introduced into Texas bays annually through the state's red drum stock enhancement program (McEachron et al. 1998). The Texas stocking program, initiated in 1983, may play an important role in enhancing the natural red drum population. The success of this program lies in the survival of released fish, and marking them with VIE is one means to assess their mortality and movement patterns.

Previous marking studies involving red drum have used oxytetracycline hydrochloride (OTC) to mark the otoliths of individuals before release (Bumguardner 1991; Szedlmayer and Howe 1995; McEachron et al. 1998; Jenkins et al. 2002). These studies found that immersing red drum in OTC can be an accurate means of marking them. However, Jenkins et al. (2002) suggested that OTC may not be appropriate for shortterm studies on small fish because the marks are not detectable on fish sampled $56 \mathrm{~d}$ after immersion owing to interference from autofluorescence. Another disadvantage of using OTC is that the fish must be sacrificed to remove the otolith for identification. Therefore, this technique is impractical for mark-recapture studies of small red drum where large numbers of fish are recaptured and marked individuals must be quickly identified in the field.

Other marking studies involving small, juvenile red drum have examined the use of coded wire microtags (Bumguardner 1990; Szedlmayer and Howe 1995), spray paint, and external plastic minitags (Szedlmayer and Howe 1995). The use of coded wire microtags is labor-intensive and the microtags have variable retention rates, depending on the tagging location (Bumguardner 1990; Szedlmayer and Howe 1995). When small, juvenile red drum (SL, 48-95 mm) were marked with spray paint and external plastic minitags, Szedlmayer and Howe (1995) found that those marked with spray paint had high mortality and low retention rates and those marked with external plastic minitags experienced significant tag loss compared with other methods, such as OTC marking. The purpose of this study was to examine the tag retention, mortality, and growth rates of juvenile red drum marked with VIE under laboratory conditions. We also assessed the usefulness of VIE in mark-recapture studies with wild and hatchery-reared red drum and performed a preliminary study on the fine-scale movement patterns of wild and hatchery-reared red drum within a sea grass meadow.

\section{Methods}

Laboratory evaluation of VIE.-To assess VIE tag retention and the effects of tagging on red drum growth and mortality, we set up 12 replicate $37.9-\mathrm{L}$ aquarium tanks $(51 \mathrm{~cm}$ long $\times 26 \mathrm{~cm}$ wide $\times 31 \mathrm{~cm}$ high $)$ to house four treatment groups (two tagged groups and two untagged control groups, with and without anesthesia). Each treatment group included three replicates of 5 fish per group (60 total fish). The tagging locations (below and parallel to the dorsal fin and above and parallel to the anal fin) were in peripheral muscle tissue away from vital organs, as suggested by Frederick (1997) and Olsen and Vøllestad (2001). Three replicate tanks were randomly assigned a tagged group or untagged control group. Hatcheryreared red drum (SL, 29.6-38.7 mm; mean length, 34.2 $\mathrm{mm}$ [SE, 0.23]) were obtained from the Texas Parks and Wildlife Department/Coastal Conservation Association (TPWD/CCA) Marine Development Center (MDC) in Flour Bluff, Texas. Three groups of red drum were anesthetized in a saltwater solution of 50 mg tricaine methanesulfonate (MS-222)/L of water for 5 min or until no longer swimming, and their SL was measured to the nearest $0.1 \mathrm{~mm}$. The fish in the tagged treatment groups were then marked with a manual injector (a $0.3-\mathrm{cm}^{3}$ insulin syringe and 29-gauge needle; Northwest Marine Technologies, Inc.). One replicate was tagged at a time, and the replicates were randomly tagged. The fish were tagged in the left or right side with one of three VIE colors (orange, yellow, or green) to differentiate among individual fish. The needle was pointed toward the front of the fish and inserted parallel to and just under the skin. The VIE was injected as the needle was retracted and stopped before the needle was removed, leaving a path of elastomer. Excess elastomer was wiped from the injection site. One untagged control group was anesthetized with MS-222 and measured. The remaining untagged control group was measured but not anesthetized. The tanks were on constant filtration; the salinity and dissolved oxygen were maintained between $25 \%$ and $30 \%$ and $6-7 \mathrm{mg} / \mathrm{mL}$, respectively. The fish were fed daily to satiation with commercial fry feed (Rangen) during the 14-d study. Each fish was measured at the end of the 14-d period. A one-way analysis of variance (ANOVA; $\alpha=0.05$ ) was used to test for differences in growth rates between treatment levels.

Field evaluation of VIE.-To examine VIE effectiveness under field conditions and assess the fine-scale movement patterns of wild-caught and hatchery-reared red drum, a field study was conducted from November through December 2005 during the peak red drum 
TABLE 1.-Laboratory evaluation of visible implant elastomer (VIE) in juvenile red drum. Two controls were used, fish that were neither anesthetized nor tagged and fish were anesthetized but not tagged. Tag retention in surviving fish was $100 \%$ for both tagging locations, and overall mortality for all treatment levels was $10 \%$. Five fish from one anal-tag replicate died simultaneously on day 4, most likely because of an unknown tank effect rather than the VIE tag. This replicate was excluded from the growth analysis. The mean growth rate was not significantly different among treatments $(P=0.176)$.

\begin{tabular}{lcccccc}
\hline Treatment group & Replicates & $N$ & Mortality & $\begin{array}{c}\text { Mean } \pm \text { SE } \\
\text { replicate mortality (\%) }\end{array}$ & $\begin{array}{c}\text { Tag } \\
\text { retention }(\%)\end{array}$ & $\begin{array}{c}\text { Growth rate } \pm \text { SE } \\
(\mathrm{mm} / \mathrm{d})\end{array}$ \\
\hline Anal tag & 3 & 5 & 6 & $40 \pm 30.5$ & 100 & $0.30 \pm 0.049$ \\
Dorsal tag & 3 & 5 & 0 & 0 & 100 & $0.43 \pm 0.087$ \\
Untreated control & 3 & 5 & 0 & 0 & n/a & $0.35 \pm 0.071$ \\
Anesthetized control & 3 & 5 & 0 & n/a & $0.56 \pm 0.074$ \\
\hline
\end{tabular}

recruitment season using wild-caught (SL, 15.2-32.7 $\mathrm{mm}$; mean length, $22.0 \mathrm{~mm}$ [SE, 0.27]) and hatcheryreared (SL, 18.8-32.0 mm; mean length, $25.6 \mathrm{~mm}$ [SE, $0.14])$ red drum marked with VIE. Wild-caught red drum $(N=150)$ were collected with a bag seine $(6 \mathrm{~m}$ long with 5-mm-mesh wings and a 3-mm-mesh bag) in sea grass meadows near the study site. The red drum were anesthetized with MS-222 and marked below the dorsal fin. This location was easier to tag and had a lower mortality rate in the laboratory study. To allow for differentiation between hatchery-reared and wildcaught red drum, we tagged hatchery-reared fish on the right side and wild-caught fish on the left side. The hatchery-reared fish were tagged in the laboratory, and the wild-caught fish were seined and tagged on site. All fish were monitored for any abnormal behavior before release. After tagging, 50 hatchery-reared and 50 wildcaught red drum were released at three replicate sites $200 \mathrm{~m}$ apart in a continuous sea grass bed of Halodule wrightii in Corpus Christi Bay, Texas $\left(27^{\circ} 49.001^{\prime} \mathrm{N}\right.$, $\left.97^{\circ} 06.892^{\prime} \mathrm{W}\right)$. Fish were marked with a different VIE color (orange, yellow, green) at each release site to enable identification and calculation of distance traveled from the release point. Sampling was accomplished by establishing a circular grid with ranges of distances $(0-15,15-30,30-45,45-60,100$, and 200 $\mathrm{m})$ from the release point. Red drum were collected by pulling a bag seine for approximately $15 \mathrm{~m}$ at three random replicate sites at each distance of the circular grid. These seining sites along each circular grid distance were randomly chosen for each sampling event. We seined for marked red drum 1, 3, 7, and $14 \mathrm{~d}$ after release. The distance from the release site to the capture site was recorded, and the fish were released.

\section{Results}

Laboratory Evaluation of VIE

We observed high tag retention and low mortality resulting from VIE tagging of red drum. No mortality occurred in the control fish. The overall tag retention and mortality of tagged fish after $14 \mathrm{~d}$ were $100 \%$ and $10 \%$, respectively. The mortality of fish tagged below the dorsal fin was $0 \%$; the fish tagged above the anal fin had a mean replicate mortality of $40 \%$ (SE, 30.5; Table 1). Overall, six red drum tagged above the anal fin died; one fish died on day 3 , and all five fish from the same anal-tagged replicate tank died on day 4 . This replicate was excluded from the growth analysis. All marks on the surviving fish were visible $14 \mathrm{~d}$ after tagging, although marks below the dorsal fin were more easily seen than those above the anal fin. An ultraviolet light and amber-shaded glasses aided in the identification of tags above the anal fin. The mean growth rate was $0.43 \mathrm{~mm} / \mathrm{d}$ (SE, 0.087) in fish tagged below the dorsal fin; $0.30 \mathrm{~mm} / \mathrm{d}$ (SE, 0.049) in fish tagged above the anal fin; $0.35 \mathrm{~mm} / \mathrm{d}$ (SE, 0.071) in the untagged, unanesthetized control; and $0.56 \mathrm{~mm} / \mathrm{d}$ (SE, 0.074) in the untagged control anesthetized with MS222. The mean growth rates were not significantly different among treatment levels $(P=0.176 ; F=2.198$; df $=3,7 ; N=3$ [anal-tagged fish, $N=2$ ] $; 1-\beta=$ 0.201 ; Table 1).

\section{Field Evaluation of VIE}

A total of 100 (50 hatchery-reared and 50 wildcaught) red drum were released at each of the three replicate sea grass beds. We recaptured $4(1.3 \%)$ of the 300 fish released. We recaptured two hatchery-reared red drum $1 \mathrm{~d}$ postrelease at distances of 15-30 and 30$45 \mathrm{~m}$ from their release point. One wild-caught and one hatchery-reared red drum were captured $3 \mathrm{~d}$ postrelease at a distance of $200 \mathrm{~m}$ from their release point. Recapture rates for hatchery-reared and wild-caught fish were $2 \%$ and $0.7 \%$, respectively. All of the VIE tags on the recaptured fish were easily visible.

\section{Discussion}

We observed that VIE marking had little effect on mortality and growth when fish were tagged dorsally. In addition, we observed $100 \%$ tag retention. Our results suggest that VIE is a viable tool for experiments requiring the identification of small, juvenile red drum. Moreover, our field experimentation suggests that VIE 
is a useful tool for tagging red drum under field conditions.

We found that the most effective tagging location in red drum was below the dorsal fin. This location allowed for less handling and easier injection of the elastomer and resulted in no mortalities. We experienced mortality rates of 0,20 , and $100 \%$ for analtagged fish in replicate tanks. Five fish from one replicate tank died simultaneously on day 4; this was most likely due to an unknown tank effect rather than to the VIE tag. The mortality of the other anal-tagged fish may have been caused by increased handling or by insertion of the needle too deeply during VIE application; tagging above the anal fin proved to be slightly more difficult than tagging below the dorsal fin. The tags below the dorsal fin were also more visible than the tags above the anal fin because the VIE may have been injected more shallowly below the dorsal fin. Frederick (1997) evaluated VIE for marking Acanthuridae and Lutjanidae spp. (SL, 10-56 mm). She marked fish in several locations, including below the dorsal fin and above the anal fin, and found that shallow injections made into peripheral musculature near the dorsal fin caused the lowest mortality. Dewey and Zigler (1996) evaluated VIE for marking bluegills Lepomis macrochirus by marking juveniles (TL, 34-55 $\mathrm{mm}$ ) in four body locations, including below the dorsal fin. Although they did not differentiate between the four tagging locations, they also found that marking did not affect the growth or survival of juvenile bluegills.

Although there were no significant differences in growth rates among our control and tagged groups, we found that anesthetized fish were much easier to handle, measure, and tag. Thus, we recommend using MS-222 anesthetic when tagging young juvenile red drum. Olsen and Vøllestad (2001) marked brown trout Salmo trutta (fork length, 28.9-44.1 mm) and found that tagging had no significant effect on growth. Frederick (1997) found that the marking success in small $(<20-\mathrm{mm})$ fish was affected by the tagging experience of the investigator. Both of these investigators stressed the importance of experience and skill in elastomer application in keeping the mortality rates low. To control for the experience level of our tagging personnel and to ensure their proficiency in applying VIE, we performed several preliminary tagging trials on juvenile red drum and other small fishes before our laboratory tagging study.

Under field conditions, we found that VIE was easy to use and the tags were visible upon recapture for juvenile red drum. We recaptured $1.3 \%$ of the released red drum within $3 \mathrm{~d}$ of release. Our recapture rates were lower than expected; this may have been because a small sample was released into a relatively large area.
The fish were released into a large continuous sea grass bed, but they could have migrated out of the study area. We are unable to make strong conclusions about the postsettlement movements of red drum owing to the low recapture rate. We hypothesized that the released red drum would have relatively small movement patterns; however, our results suggest that young red drum of this size have a much larger dispersal potential than previously suspected (Holt et al. 1983), and assessing movement patterns of young juvenile red drum merits further investigation.

In summary, VIE is relatively inexpensive and easy to apply. It has high retention rates, low mortality when fish are tagged dorsally, and no effect on the growth rate. This method is useful for tagging small numbers of fish and is practical for relatively small-scale, shortterm studies where the identification of individual fish is not necessary.

\section{Acknowledgments}

Funding for this study was provided by the Coastal Bend Bays and Estuaries Program, Coastal Conservation Association, and Texas A\&M University-Corpus Christi (TAMU-CC). This research was conducted through the Fishery Ecology Laboratory at TAMU-CC. Help from laboratory personnel was essential for the successful completion of this project. Special thanks to Sarah Bayer, Annette Cardona, Ryan Fikes, Jason James, and Todd Neahr for their assistance in the laboratory and field. We gratefully acknowledge the Texas Parks and Wildlife Department, especially Robert Vega and Rodney Gamez for their assistance and for providing the hatchery-reared red drum used in this study.

\section{References}

Bonneau, J. L., R. F. Thurow, and D. L. Scarnecchia. 1995. Capture, marking, and enumeration of juvenile bull trout and cutthroat trout in small, low-conductivity streams. North American Journal of Fisheries Management 15:563-568.

Brennan, N. P., K. M. Leber, H. L. Blankenship, J. M. Ransier, and R. Debruler. 2005. An evaluation of coded wire and elastomer tag performance in juvenile common snook under field and laboratory conditions. North American Journal of Fisheries Management 25:437-445.

Bumguardner, B. W. 1990. Tag retention, survival, and growth of red drum fingerlings marked with coded wire tags. Pages 286-292 in N. C. Parker, A. E. Giorgi, R. C. Heidinger, D. B. Jester, Jr., E. D. Prince, and G. A. Winans, editors. Fish-marking techniques. American Fisheries Society, Symposium 7, Bethesda, Maryland.

Bumguardner, B. W. 1991. Marking subadult red drums with oxytetracycline. Transactions of the American Fisheries Society 120:537-540.

Catalano, M. J., S. R. Chipps, M. A. Bouchard, and D. H. 
Wahl. 2001. Evaluation of injectable fluorescent tags for marking centrarchid fishes: retention rate and effects on vulnerability to predation. North American Journal of Fisheries Management 21:911-917.

Close, T. L. 2000. Detection and retention of postocular visible implant elastomer in fingerling rainbow trout. North American Journal of Fisheries Management 20:542-545.

Close, T. L., and T. S. Jones. 2002. Detection of visible implant elastomer in fingerling and yearling rainbow trout. North American Journal of Fisheries Management 22:961-964.

Dewey, M. R., and S. J. Zigler. 1996. An evaluation of fluorescent elastomer for marking bluegills in experimental studies. Progressive Fish-Culturist 58:219-220.

Fitzgerald, J. L., T. F. Sheehan, and J. F. Kocik. 2004. Visibility of visual implant elastomer tags in Atlantic salmon reared for two years in marine net-pens. North American Journal of Fisheries Management 24:222-227.

Frederick, J. L. 1997. Evaluation of fluorescent elastomer injection as a method for marking small fish. Bulletin of Marine Science 61:399-408.

Goldsmith, R. J., G. P. Closs, and H. Steen. 2003. Evaluation of visible implant elastomer for individual marking of small perch and common bully. Journal of Fish Biology 63:631-636.

Guy, C. S., H. L. Blankenship, and L. A. Nielson. 1996. Tagging and marking. Pages 353-379 in B. R. Murphy and D. W. Willis, editors. Fisheries techniques, 2nd edition. American Fisheries Society, Bethesda, Maryland.

Haines, G. B., and T. Modde. 1996. Evaluation of marking techniques to estimate population size and first-year survival of Colorado squawfish. North American Journal of Fisheries Management 16:905-912.

Hale, R. S., and J. H. Gray. 1998. Retention and detection of coded wire tags and elastomer tags in trout. North American Journal of Fisheries Management 18:197-201.

Hendricks, M. L., D. L. Torsello, and T. W. H. Backman. 1994. Use of otolith microstructure to distinguish wild from hatchery-reared American shad in the Susquehanna River. North American Journal of Fisheries Management 14:151-161.

Holt, S. A., C. L. Kitting, and C. R. Arnold. 1983. Distribution of young red drums among different seagrass meadows. Transactions of the American Fisheries Society 112:267271.

Jenkins, W. E., M. R. Denson, C. B. Bridgham, M. R. Collins, and T. J. Smith. 2002. Retention of oxytetracyclineinduced marks on the sagittae of red drum. North American Journal of Fisheries Management 22:590-594.
King, T. L., R. Ward, and I. R. Blandon. 1993. Gene marking: a viable assessment method. Fisheries 18(2):4-5.

Malone, J. C., G. E. Forrester, and M. A. Steele. 1999. Effects of subcutaneous microtags on the growth, survival, and vulnerability to predation of small reef fishes. Journal of Experimental Marine Biology and Ecology 237:243253.

McEachron, L. W., R. L. Colura, B. W. Bumguardner, and R. Ward. 1998. Survival of stocked red drum in Texas. Bulletin of Marine Science 62:359-368.

McFarlane, G. A., R. S. Wydoski, and E. D. Prince. 1990. Historical review of the development of external tags and marks. Pages 9-29 in N. C. Parker, A. E. Giorgi, R. C. Heidinger, D. B. Jester, Jr., E. D. Prince, and G. A. Winans, editors. Fish-marking techniques. American Fisheries Society, Symposium 7, Bethesda, Maryland.

Morgan, R. G., and D. S. Paveley. 1996. A simple batch mark for fish studies using injected elastomer. Aquaculture Research 27:631-633.

Negus, M. T. 1999. Thermal marking of otoliths in lake trout sac fry. North American Journal of Fisheries Management 19:127-140.

Olsen, E. M., J. Gjøsæter, and N. C. Stenseth. 2004. Evaluation of the use of visible implant tags in age- 0 Atlantic cod. North American Journal of Fisheries Management 24:282-286.

Olsen, E. M., and L. A. Vøllestad. 2001. An evaluation of visible implant elastomer for marking age-0 brown trout. North American Journal of Fisheries Management 21:967-970.

Pattillo, M. E., T. E. Czapla, D. M. Nelson, and M. E. Monaco. 1997. Distribution and abundance of fishes and invertebrates in Gulf of Mexico estuaries, volume 2. Species life history summaries. National Oceanic and Atmospheric Administration, Estuarine Living Marine Resources Program, Report 11, Silver Spring, Maryland.

Rooker, J. R., G. J. Holt, and S. A. Holt. 1997. Condition of larval and juvenile red drum (Sciaenops ocellatus) from estuarine nursery habitats. Marine Biology 127:387-394.

Rooker, J. R., G. J. Holt, and S. A. Holt. 1998a. Vulnerability of newly settled red drum (Sciaenops ocellatus) to predatory fish: is early-life survival enhanced by seagrass meadows? Marine Biology 131:145-151.

Rooker, J. R., S. A. Holt, M. A. Soto, and G. J. Holt. 1998b. Post-settlement patterns of habitat use by sciaenid fishes in subtropical seagrass meadows. Estuaries 21:315-324.

Szedlmayer, S. T., and J. C. Howe. 1995. An evaluation of six marking methods for age-0 red drum, Sciaenops ocellatus. U.S. National Marine Fisheries Service Fishery Bulletin 93:191-195. 